\title{
Change in contemporary Italy's social concertation
}

\section{Serafino Negrelli and Valeria Pulignano}

\begin{abstract}
This article examines the crisis of social concertation in Italy since 2000 . We argue that this crisis is not due exclusively to the political shift from a centre-left to a centre-right government led by Silvio Berlusconi, or the end of the European integration phase. It reflects the continued failure of Italian social concertation to address problems of economic growth and work productivity was apparent by the second half of the 1990s. We argue that this is due mainly to the stagnation of the decentralisation process at the company and territorial levels and, in particular, the limited development of second-level collective bargaining introduced by the 1993 July Ciampi Protocol. This reflects a weakness in the Italian institutional context as well as the difficulties associated with the altering of industrial relations in global market economies more generally. The prospects for the future of concertative policy making in the Italian context are also discussed.
\end{abstract}

\section{INTRODUCTION}

Across several European countries in the 1990s, governments and organised interests concluded a series of tripartite agreements on income policy, collective bargaining rules and employment promotion measures (Hassel, 2003; Schmitter and Grote, 1997). These practices emerged in the context of a number of prevailing national economic and socio-political conditions. For example, in contrast to the Netherlands and Ireland - where the process of centralisation started well before the 1991 Maastricht Treaty - in Greece, Italy and Portugal the political-economic pressure for the European Monetary Union (EMU) proved crucial in the emergence of social pacts and the national coordination of wage bargaining in the 1990s (Léonard, 2001).

The main characteristics and success of social pacts in Europe depended mainly on 'the strategies of the social actors as well as on the respective national features' (Negrelli, 2000: 102). In the Italian case, Regini (1997) makes the point that the widely shared objective between trade unions and employers to improve national

$\square$ Serafino Negrelli is Professor of Industrial Relations, Work and Economic Sociology, University of Brescia, Italy, and Valeria Pulignano is Professor of Sociology of Labour and Industrial Relations at the Catholic University of Leuven, Belgium, and Associate Fellow IROB-IRRU, University of Warwick, UK. The authors are listed in alphabetical order. Correspondence should be addressed to Valeria Pulignano, Katholieke Universiteit, Faculty of Social Sciences, Centre for Sociological Research (CESO), E. Van Evenstraat 2B, B-3000, Leuven, Belgium; email: valeria.pulignano@soc.kuleuven.be 
competitiveness was the basis for the success of national social concertation in the 1990s. ${ }^{1}$ In brief, the Italian social consensus to meet European monetary targets was achieved through 'the participation of centralized and strong interest organizations to which national governments devolve regulative policy-making functions' (Regini, 1997: 268). As Rhodes (2001) argues, 'coalition building' is required for successful social pacts.

The mutual interest of the social partners in creating socio-economic stability in light of the emerging EMU process affected the extent to which (and how) social pacts were implemented throughout Europe (Siegel, 2005). In the Netherlands, during a period of socio-economic urgency, social pacts were driven by the trade unions' willingness to promote 'job creation' on the one hand, and the employers' interests to increase profitability in the international market on the other (Visser, 1998). In Ireland, 'social partnership' agreements were the result of the mutual aims of Government, employers and trade unions to increase national competitiveness and to produce common gains after a period of economic crisis (Gunnigle et al., 1999; Roche and Geary, 2000). Likewise, sensitive social reforms in Italy in the early 1990s were promoted by the common interests of the trade unions and the employers' confederations to re-establish economic growth in a period of socio-economic instability (Negrelli, 2000). Hancke and Rhodes (2005) argue that the end of the EMU integration process will cause a crisis of social pacts in Europe. More specifically, in considering the case of Italy, Ferrera and Gualmini (2004) claim that 'the entry of Italy into EMU seemed to be the last issue on which consensus was needed: after that no shared goal appears on the political stage' (ibid.: 146-147). Thus, the Italian experience looks interesting. After a period of a 'veritable resurgence of social concertation' in the 1990s (Regini, 1997: 261), there currently seems to be less urgency to seek social consensus. Why?

We argue that the crisis of social concertation in Italy since 2000 is not exclusively because of contingent factors such as the emergence of the 2001 new centre-right government led by Silvio Berlusconi or the end of the EMU integration phase; instead, it mainly reflects specific country-based difficulties and limits. Specifically, this involves the inability of social concertation to deal effectively with broad economic and social reforms, especially implementation of the collective bargaining review process of decentralisation at the company and territory levels, formerly introduced by the 1993 July Ciampi Protocol. As the Protocol indicates, the development of the second level of decentralisation would have supported the creation of an industrial relations system in which the achievement of low inflation and national economic stability, through wage coordination and moderation, could have arguably been followed by an increase in national economic growth and productivity; however, divergent opinions between (and within) employers and trade unions concerning how to implement decentralisation generated political confusion and prevented the implementation of what had been agreed earlier in the 1993 July Protocol. This reflects the institutional weaknesses of Italy's industrial relations system and in particular the lack of a stable framework of rules of interest representation. In the early 1990s, the success of the Italian social pact was attributed to pressure in support of the process of European integration, which led to institutional changes in the Italian industrial

\footnotetext{
${ }^{1}$ In the Italian tradition of industrial relations, 'social concertation' is a method for planning economic policy measures by formulating tripartite agreements between the government, the employers' organisation and the trade unions (Alacevich and Burroni, 2001). 
relations system. Since 2000, the lack of willingness by the national social partners to continue along the road of such reform has restricted the opportunity for social concertation. In the recent context of 'zero' productivity growth, it is uncertain to what extent (and how) social concertation will accompany the future framework for social and political reforms in Italy's industrial relations. Can we expect a recovery of social concertation under the centre-left government led by Romano Prodi, which won the Italian election of April 2006? As this article illustrates, the answer to this question depends on the ability of the Prodi government to re-establish the process of social concertation while seeking to resolve the institutional weaknesses of the Italian system of industrial relations.

\section{THE 'GOLDEN AGE' OF CONCERTATION: THE 1993 CIAMPI PROTOCOL AND THE 1996 PACT FOR EMPLOYMENT}

The European experience illustrates that the development of social consensus in the 1990s was accompanied by a diverse and varied range of socio-economic and political features. As previously indicated, these features represent the European imperatives of the Treaty of Maastricht and the EMU, which have led some Member States, such as Italy, to adjust fiscal and monetary policies in order to promote higher rates of economic growth and meet the economic convergence criteria, while at the same time reducing inflation and public debt.

In contrast to the experiences of other European countries, the adoption by Italy of welfare policies and a more active labour market was accelerated via the negotiation of bipartite and tripartite agreements. Moreover, the national pattern of social pacts in the early 1990s was brought about by way of 'shared leadership' between a strong employers' association (the Confindustria) and equally strong national trade union confederations [Confederazione Generale Italiana del Lavoro (CGIL), Confederazione Italiana Sindacati Lavoratori (CISL) and Unione Italiana del Lavoro (UIL)]. This occurred during a period in which the government and the political system were at their weakest point since the postwar period (Negrelli, 2000: 101-106). We refer here to the collapse of the Christian Democracy coalition, which had dominated the political arena for almost 50 years. Following the crisis, linked to a succession of corruption scandals (i.e. 'Mani Pulite' or 'Clean Hands'), CGIL, CISL and UIL gradually distanced themselves from the political system. The absence of a concrete political project created the political conditions for the trade unions to become directly involved as (arguably) the main actor in the process of concertation with the government and the employers' organisation. As Regini (1997: 268) argues, authority was devolved to the interested organisations (especially to trade unions) in a framework of concertative policy making. It can also be argued that in the 1990s the Italian trade unions had a strong organisational structure that enabled them to be actively involved in wage moderation (Salvati, 2000). In addition, the economic and financial crisis and the reduction in (high levels of) public debt required to enter the EMU reinforced the need for urgency between the social partners and the government in negotiations over collective bargaining, income policies and pension reform. Thus, in a context of institutional and economic emergency, which mainly coincided with the European integration process, social concertation was considered the cornerstone for regulative policies (Regini, 2000). More specifically, fiscal drag, labour market, labour, income and welfare policies were addressed in new tripartite agreements between the government and the social partners during the 1990s. 
However, to suggest that European integration is the only explanation for the emergence of social concertation is inadequate. As Léonard (2005) recently argued, by looking at the European experience more generally, we need to understand the endogenous dynamics surrounding the process of social negotiation in order to assess national actions and outcomes. More specifically, Salvati (2000) illustrates that the success of social concertation in Italy in the early 1990s was the result of a convergence of the interests of the national social partners. In particular, besides the need to meet the Maastricht convergence criteria, Confindustria and the main Italian union confederations were convinced that social negotiation was the mechanism by which to overcome the political and social difficulties created by the 'Clean Hands' scandal. Furthermore, in a period characterised by high unemployment and declining union presence, political exchange through social negotiation appeared to be the most likely and effective means by which trade unions could exercise greater influence.

An example of concertation in Italy in the 1990s is the July 1993 tripartite agreement on income policy, reached under the 'technocratic government' headed by Ciampi. The 1993 agreement was characterised by trade union involvement in wage moderation and it succeeded in establishing a stable framework for income policy and bargaining relations. The agreement addressed some of the problems of the previous July 1992 agreement established under the Amato government. The 1992 agreement abolished the system of wage indexation (the scala mobile) by curbing wage growth without the compensatory measures that had accompanied the political tradeoffs made in the early 1980s. ${ }^{2}$ This resulted in a failure to introduce new rules and procedures in the collective bargaining system (Regalia and Regini, 2004). Conversely, the July 1993 agreement confirmed the abolition of the scala mobile and delineated a new structure of income policies and collective bargaining. In particular, the protocol established a new bargaining structure that is based on two levels of bargaining: national industrial-sector bargaining every four years (every two years for wages) and decentralised bargaining (alternatively at the company or territory level every four years, but only for wages linked to productivity, quality and profitability indicators). The main purpose of the agreement was to establish rules and procedures for the conduct of collective bargaining, but it was not intended to constrain industryand company-level negotiations (Alacevich and Burroni, 2001). Hence, the agreement linked wage increases to company performance and encouraged negotiations to take place at a decentralised level. Some of the principles of decentralised company-level bargaining were established in the agreement. Visser and Hemerijck (1997) highlight the existence of a balance between centralised and decentralised bargaining forces; nevertheless, in the case of Italy, this balance has often been weak, as it depended primarily on a delicate balance of power. Traditionally, Confindustria and the three main Italian union confederations disagreed on the extent to which collective bargaining could be decentralised. On the one hand, the former was usually in favour of excluding small enterprises from decentralised collective bargaining; on the other, CGIL wanted (and still prefers) to maintain the traditional strength and role of the centralised national collective agreement, whereas CISL and UIL are in favour of greater equilibrium between the centralised and decentralised levels.

\footnotetext{
${ }^{2}$ The scala mobile (system of wage indexation) automatically linked wages to the inflation rate. The degree of linkage oscillated around 80 per cent during the 1970s before undergoing significant reductions from 1986 (Regalia and Regini, 1998). 
As we illustrate later in the text, permanent disagreements slowed down the process of decentralising bargaining in Italy. Indeed, despite some sector-based exceptions, there has been no general follow-up on the decentralisation of the structure of collective bargaining in the subsequent tripartite agreements. As Bellardi (1999) explains, the traditions and natures of the different sectors played a relevant role in shaping the extent to which the structure of collective bargaining was decentralised. For example, in the metalworking, food, printing and banking sectors, decentralisation is not an issue. Company-level bargaining is expected in the national industry agreement [the Contratto Collettivo Nazionale di Lavoro (CCNL)] as a possible but not formal level of bargaining. In contrast, the national industry agreement in the handcraft and agriculture sectors indicates that decentralisation often occurs at both the territory and company levels. Furthermore, in tourism and commerce, national social partners can choose to decentralise at the territory or company level.

Income policies and the reform of the collective bargaining system have been the most important aspects of social pacts, but not the only objectives. As highlighted by Regalia and Regini (1997), further key areas of reform are the social security system, public-sector collective bargaining and measures to increase employment. ${ }^{3}$ After the breakdown of social relations with the trade unions, as a guarantee for social consensus, the first Berlusconi government in 1994 attempted to cut public spending, unilaterally reform the pension system and, for the first time, directly challenge the pillar of social concertation. However, the following wave of strike activity and social unrest led by the Italian trade unions unequivocally marginalised political negotiations on reform of the pension system and led to the abolition of the Budget Law. This occurred without the government obtaining social consensus. Pension reform was approved in 1995 and adopted by the caretaker of another 'technocratic government' headed by Dini (who had held the position of Minister of Finance under Berlusconi); the reform was negotiated between the government and the trade unions. The employers' association withdrew from discussions at an early stage on the grounds that the reform did not go far enough.

Regalia and Regini (2004) argue that the Italian pension reform involved 'bilateral concertation' because it primarily implied a process of consultation between the government and the three major trade union confederations. Conversely, some more radical commentators suggest that a concertation process that takes place under the shadow of a severe crisis of the political system and with the agreement of only one actor may be considered 'imperfect' (Siegel, 2005). It may also be claimed that the reform of the pension system was primarily aimed at protecting the interests of the workers who voted (in majority) in favour of the reform in the referendum conducted by the trade unions in 1995 (Giugni, 2003). The referendum followed the conversion of the text of the reform into a bill, which was submitted to the Parliament and approved in 1995. The new 'negotiated' law was hailed as one of the preconditions, along with the tripartite agreements of 1992 and 1993, of Italy's subsequent economic recovery.

A similar discussion concerning the genuine 'concertative' nature of the negotiation process has taken place regarding the agreement on employment ('Pact for

\footnotetext{
${ }^{3}$ The privatisation process, which accompanied the reform of the public sector, was undertaken in light of extensive consultation and negotiation involving the unions and the government. As a result, collective bargaining in the public sector regulated the employment of civil servants. A technical agency [the Agenzia per le relazioni sindacali (ARAN)] later took on the task of representing the government in its role as employer in collective negotiations.
} 
employment'), which was reached under the government headed by Prodi in 1996. The pact was consequently transformed into the so-called Pacchetto Treu for the introduction of more flexible labour market measures. The provisions of the pact were implemented via a 1997 law that for the first time formally allowed temporary agency work, addressed fixed-term employment, provided incentives for part-time work and redefined working time schedules. New rules were also introduced to relaunch the apprenticeship system, to develop training contracts and supplementary training and, more importantly, to implement 'territorial pacts' to introduce new investment in economically underdeveloped regions. The agreement was accompanied by a process of information and consultation with the social parties rather than political negotiation and tripartite concertation between the government and interested organisations. Hence, Giugni (2003) argues that the agreement has made only a weak contribution to progress along the road of social consultation. This is because legislation, rather than the formal definition of procedural and substantial rules, was used to achieve social consensus; however, the agreement was also unsuccessful in balancing centralised and decentralised collective bargaining as originally envisaged in the 1993 tripartite agreement.

\section{THE DECLINE OF CONCERTATION: FAILURE OF THE 1998 'CHRISTMAS PACT' AND THE CRISIS OF COLLECTIVE BARGAINING DECENTRALISATION}

The crisis of social concertation in Italy appears to have strongly coincided with the failure of the 1998 social pact ('Christmas Pact') signed by the Italian government and more than 30 employers' associations and the trade unions. In reality, we need to examine the events of the previous year and consider the bitter 1997 dispute orchestrated by the metalworking unions over the controversial 1993 Ciampi Protocol (Dell'Aringa and Negrelli, 2005; Negrelli, 2006). A special committee (chaired by Giugni) was set up under the Prodi government in 1997 to verify the implementation of the 1993 protocol, established after a four-year period. The findings of the committee pointed to the problematic effects that arose from the structure of companyand territory-level collective bargaining as originally introduced by the 1993 protocol. The main problem concerned ambiguity between the expected and actual inflation rate in the new parameters designed (in the protocol) to guarantee coverage of such increases in the annual inflation rate. The vagueness of the two terms generated diverse expectations by the trade unions and the employer organisations. While trade unions saw the protocol as introducing an innovative structure for negotiation with the employers, employers considered it less innovative, but effective evidence to reduce salary increases in the process. The effect was to constrain the implementation of a decentralised level of collective bargaining as the 1993 Protocol had originally intended.

Employers in most cases strongly supported decentralised bargaining because the reduction in the inflation rate had deprived industry-level bargaining of its main content; however, they felt no need to actively cooperate in its implementation. On the one hand, employers considered it crucial that the process of decentralisation should maintain two levels of bargaining (i.e. company and territorial), as this was a means to increase flexibility in the labour market. On the other hand, they supported the idea that a shift towards decentralised company bargaining was necessary to link productivity and pay. Nevertheless, the employers themselves, representing the interests of 
companies of different sizes, disagreed on the appropriate level of decentralisation, whether at the company level of medium- and large-sized firms or at the territory level for small firms (Regalia and Regini, 2004). This climate affected the context in which the social partners set the agenda for the new tripartite agreement that was signed in December 1998 (the 'Christmas Pact'). The agreement aimed to establish through social concertation, among other things, a collective bargaining structure in accordance with the content of the 1993 Protocol. Nevertheless, because of the disagreements among employers previously mentioned, the final text of the 'Christmas Pact' did not mention the structure of collective bargaining; moreover, it did not take into consideration the observations of the 1997 special committee. Thus, the 1998 social pact was not as socially and politically influential as it should have been. Although it aimed to promote economic development and employment growth - namely innovation and the development of companies and employment and economic infrastructures through the strengthening of the territory-level bargaining structure - it did not create a unique platform for collective bargaining decentralisation as initiated in the 1993 tripartite agreement. Hence, innovative government proposals for economic development and increased employment through territory-level collective agreements (i.e. patti territoriali or territorial pacts) (Negrelli, 2004) encountered a lack of commitment by the social partners in negotiating these proposals (Salvati, 2000). This lack of enthusiasm can be explained by the deteriorating relationship between (and within) employers' organisations and trade unions. In fact, the employers' internal disagreement on the structure of decentralised collective bargaining was soon followed by internal ideological divisions among the CGIL, CISL and UIL. The resulting political climate was unfavourable to the further development of the concertative approaches of the early 1990s.

Carrieri (2001) defined the 1998 agreement as 'a concertative tripartite social pact' implemented to develop a regional structure of bargaining and concertation. This suggests that concertation is a method of social regulation that contains both political and social aspects. Paradoxically, Giugni (2003) suggests that these features may explain the inability of the 1998 'Christmas Pact' to further the process of concertative policy making initiated by the 1993 Ciampi Protocol. Giugni (2003) goes on to explain that the crisis of the social pact in Italy in the second half of the 1990s was the inevitable consequence of a lack of enthusiasm towards concertation shown by the centre-left parliamentary majority headed by D'Alema in 1996. Reasons for such a lack of intent can be found in the weak social and political structure of this government, with its main and ambiguous objective being 'to please everybody in order not to disappoint anybody' (Dell'Aringa and Negrelli, 2005: 167).

Hence, as the scope of Italian social concertation (national, regional and local) broadened, its effectiveness decreased (Regalia and Regini, 2004). It appears that in the second half of the 1990s, new objectives such as employment creation, training, labour market and welfare reforms, were far more difficult to achieve through concertative policy making than the income policy of the early 1990s. In addition, modification of the relations between the national political system and the trade unions strongly affected the context of Italy's industrial relations (Mariucci, 2004). As previously indicated, social concertation in Italy in the early 1990s occurred within a context of 'shared objectives' and related practices in national politics. Faced with the institutional crisis of the political parties, stability was created via unification of the interests of the national industrial relations actors. The trade unions in particular, by strengthening their mediating role, were able to negotiate institutional and 
socio-economic reforms with the government. Conversely, in the late 1990s, the ideological diversity of Italian unions re-emerged and was exacerbated by the new political leadership of the centre-right government; this negatively affected the chances of obtaining social consensus.

\section{ITALY'S INDUSTRIAL RELATIONS FROM 2000: A CHANGING POLITICAL FRAMEWORK}

The 1998 'Christmas Pact' brought about a crisis of concertation and a change in Italy's political environment sanctioned the abandonment of social concertation as a method of policy making. In May 2001, a new government came to power in Italy, supported by a centre-right coalition and headed by Silvio Berlusconi, who became Prime Minister for a second time. Berlusconi had a clear working majority in both houses of Parliament without having to rely on the support of his coalition partners. The official opposition was headed by Francesco Rutelli, the defeated head of the centre-left coalition. The large parliamentary majority of the new centre-right government enabled it to claim a political mandate. On the one hand, Berlusconi had claimed to be close enough to the electorate to drive through institutional and social reforms without political negotiation with the social partners. On the other hand, the parliamentary majority enabled the new centre-right government to enhance institutional reforms without seeking social consensus (Mania and Sateriale, 2002). For example, at the beginning of the 2000s, 'Confindustria' pushed to simplify social dialogue in conjunction with the new centre-right government. The aim was to encourage labour market flexibility and the growth of atypical employment without seeking consensus from the trade unions.

The method of social concertation was formally abandoned in the White Paper on the labour market presented by the Italian government in October 2001. In this document, the term 'social concertation' was replaced by the hazy concept of 'social dialogue', without real consultation or negotiation with the social partners. The White Paper contained the government's programme of measures to enhance labour market flexibility, encouraging intermittent work, project work and 'on-call work'. The article contained a vague guarantee by the government to replace the income policy to enhance the level of national competitiveness. ${ }^{4}$ In addition, the White Paper introduced a modification of Article 18 of the Statute of Workers' Rights (Statuto dei diritti dei lavoratori-Law 300/1970). This statute, as well as providing a considerable raft of union rights, requires employers with 15 employees or more to reinstate workers if they are dismissed without 'justifiable reason' or 'just cause'. The threat to Article 18 provoked extensive social protest and a general strike organised by the three main trade union confederations, with approximately three million people demonstrating in Rome against the government's proposals in 2002 (Pulignano, 2003). Union solidarity during this protest did not last, as CISL and UIL (with the support of autonomous unions CISAL and UGL) signed the 'Pact for Italy' with the government in July 2002, whereas CGIL refused to do so. ${ }^{5}$ The 'Pact for Italy', which

\footnotetext{
${ }^{4}$ The actions mentioned in the White Paper concerning the labour market were transposed into the national Law n.30 2003.

${ }^{5}$ CGIL believed that the pact could not promote employment and economic development because it did not include protection measures for young people, illegal work and other important social measures. In addition, CGIL considered the pact a further attempt by the government to avoid direct confrontation with organised labour.
} 
came into force in 2003 (EIRR, 2003), enabled the government to divide the labour movement and push through reforms. The pact laid down guidelines on the reform of the labour market and tax system, and on measures for employment and investment in the south of Italy. It also limited the reform of Article 18 for a temporary period with regard to businesses with fewer than 15 employees.

The content of the 'Pact for Italy' is similar to the various social pacts concerning employment signed in Europe over the past decade; however, it also included novel measures for social party participation in managing certain aspects of the labour market. Although the pact acknowledged the role that concertation played in the 1993 tripartite agreement, as previously indicated, the government clearly intended to shift from political negotiation (or social concertation) to softer forms of 'social dialogue' as the new method in implementing institutional reforms.

Regini (1997) questions some of the assumptions of neo-corporatist theory associated with the emergence of concertation in modern economies. One of these assumptions is to consider concertation as the outcome of a pro-labour government. Traxler et al. (2001) refer to a specific variety of macro-concertation, namely Keynesian coordination. Italian political changes in 2000 had an impact on the transformation in social concertation; however, the crisis of concertation does not solely reflect political changes arising from modifications of the labour market introduced by the White Paper. As suggested by the detailed analysis presented in the following section, the causes of such a crisis are more varied and deep-rooted within the inability of social concertation to resolve crucial matters beyond the usual framework of economic recovery initiatives.

\section{ASSESSING CONTEMPORARY ITALIAN SOCIAL CONCERTATION}

The 1993 Ciampi Protocol included a strong emphasis on the social policy debate concerning employment and collective bargaining. The protocol established the need to confirm and continuously review the structure of decentralised collective bargaining in future social agreements; however, as previously indicated, this was already absent under the D'Alema centre-left government at the end of 1990s and, therefore, well before the date that the Berlusconi government came to power. Moreover, disagreements between (and within) Confindustria and the trade unions aggravated the political climate. In particular, Confindustria was-because of its own internal divisions and disagreements - unwilling to cooperate with the implementation of decentralised collective bargaining (Tronti, 2003). Moreover, because of the 'wage moderation' effects, decentralised bargaining would have arguably stimulated the development of income policy based on an equal distribution of productivity outcomes and, thereby, contributed to a reduction in the risk of the declining purchasing power of income (Carrieri, 2003); however, as argued by Treu (2001), the political weakness of industrial relations institutions undermined the use of social consensus as a method for implementing social reforms in Italy. In particular, social actors were uncertain regarding the extent to which the collective bargaining structure could have been changed as the result of tripartite or bipartite negotiations. For example, neither the 1996 agreement nor the 1998 'Christmas Pact' formally created a constitution of concerted action to decentralise collective bargaining with the aim of extending concertation to a range of new policy areas, including training and employment creation. Hence, despite the provisions for a review of the collective bargaining structure under the 1993 protocol, this matter and its implementation was clearly excluded from the 
negotiations for social pacts at the end of the 1990s. There was only a limited attempt to include the regional and local governments in the process of social concertation, with no reference to any matters concerning collective bargaining.

Hence, the matter under discussion is to what extent social concertation has enabled Italy to deal effectively with economic and social reforms that are not necessarily solely linked to initiatives of economic recovery. As indicated, the difficulty in progressing towards these reforms became apparent in Italy, not only via developments in national, decentralised company- and territory-level bargaining, but also via difficulties that accompanied the process of implementing European legislation since 2000. For example, the debate first concentrated on the extensive talks between Confindustria, CGIL, CISL and UIL on reforming the end-of-service allowance scheme in 2001. The debate then extended to other issues, notably the transposition of the EU directive on fixed-term work and the suitability of signing separate agreements when the parties fail to reach a common agreement. An attempt to reintroduce social negotiation was made in 2001, when Confindustria proposed to reach an accord covering pensions, labour market regulation, investment and training; however, the 'Pact for Italy' was signed in July 2002. This event followed an agreement on 'irregular work' that was signed in July 2002 and the launch in early 2003 of a bilateral dialogue on infrastructure and energy, research and innovation, and training and development in the Italian south. In reality, in the absence of any clear commitment by the Berlusconi government, such pacts amounted to little more than statements of intent or joint lobbying by trade unions and employers, with no real influence on government policy making.

As previously stated, one of the main difficulties in using social concertation in contemporary Italy was the problem of reaching agreements concerning the implementation of the review process introduced by the 1993 accord, such as the dual-level bargaining structure, with its particular focus on company- and territory-level bargaining. This highlights another crucial and problematic element in recent years: the problems of concertation itself. In particular, we refer to the lack of a stable framework of rules on representativeness and representation rights. This is a traditional problem in Italy's industrial relations, one that concerns both employers and trade union organisations. Article 39 of the Italian Constitution establishes the principle of the extension erga omnes (or automatically applicable 'in relation to everyone') of the collective agreements under certain conditions, i.e. collective agreements concluded by representative bodies, where registered trade unions are represented in proportion to their membership. But without any supporting legislation, Article 39 has never been enforceable. Thereby, the extension of collective agreements is based on a de facto industrial relations system. ${ }^{6}$ CGIL was traditionally (and still is) in favour of developing a law on union representativeness, one that would extend the current rules in the public sector (a mixed criterion of votes and membership). In contrast, CISL and UIL are against any initiative oriented to limit their voluntary and autonomous union action.

Hence, the use of social consensus in tripartite agreements primarily depends on the extent to which the social actors are representatives of the interests they claim to

\footnotetext{
${ }^{6}$ For a more detailed explanation, see Napoli, 'Il quadro giuridico istituzionale', in Cella and Treu (1998); related issues in the European Employment and Industrial Relations Glossary: Italy, edited by the European Foundation for the Improvement of Living and Working Conditions (1991) and Negrelli and Sheldon (2004).
} 
represent. This implies political stability and no internal divisions of the social institutions concerned, such as trade unions and employer organisations. More specifically, the credibility of the national government and its administrative ability are crucial factors in initiating social concertation. These factors entail unity and cohesion among (and within) the social actors - in particular the trade unions. While the three main Italian trade union confederations seem to have improved their level of representation in recent years, Confindustria continues to suffer from internal divisions (e.g. between small and big firms) that strongly affect its representative capacity and, thereby, place at risk the breadth of social negotiation.

\section{CONCLUSIONS}

Social concertation in Italy's industrial relations has been marked by a series of transformations over the past 20 years. The upsurge in Italian social consensus was signified by the 1993 Ciampi Protocol; however, the 1998 'Christmas Pact' formally signalled the decline of social concertation. In this article, we argued that this decline is not contingent upon the rise of the Berlusconi centre-right parliamentary majority in 2001 or the end of the economic process of integration (concerning the EMU); instead, the reasons for the decline in social concertation in Italy need to be found in the inability of concertation to implement the content of the 1993 Ciampi Protocol, in particular, the collective bargaining review process of decentralisation at the company and territory levels.

Some commentators have suggested that the 1993 Ciampi Protocol was just an agreement of rules that had to be developed in a shared plan of future action in order to affect the pattern of industrial relations (Regini, 2000). The experience of Italy's industrial relations in recent years confirms such an argument. Specifically, it illustrates that the framework provided by the 1993 protocol had little follow-up in the social pacts negotiated since the mid-1990s. The result was a deterioration of the content of the 1993 agreement, especially with regard to collective bargaining issues. Thus, it may be argued that the new centre-right government elected in 2001 inherited a measured framework for negotiating institutional and political stability; in such circumstances, Berlusconi was able to promote social dialogue instead of concertation. Thus, national institutional and political stability certainly affected the extent that (and the way in which) social concertation could have revitalised Italy's industrial relations. Accordingly, Salvati (2000) highlights a number of factors as being crucial for such a revitalisation. First, the presence of a government that is not only pro-labour but also able to encourage social consensus, whether in a situation of economic emergency or otherwise. Second, considerable reduction in the scale of disagreements and divisions between (and within) the organisations representing employer and employee interests. Third, the content and nature of the policies that are adopted in social negotiation, with a specific focus on development, growth, employment and social equity issues. With specific reference to Italy, Treu (2001) argues that these policies should have four main priorities: the development of a system of industrial relations at the European level as the most efficient way to deal with the current effects of internationalisation; the re-establishment of a programme of income policies which overcomes the impasse represented by the ambiguity of the expected and actual inflation rate; the implementation of decentralised bargaining - especially at the territory level - in accordance with what was already initiated by the 1993 Ciampi Protocol; and finally, regulation of the labour markets. 
In addition, when examining the current perspectives on social concertation in Italy, we need to take into consideration specific trends in the Italian socio-economic, institutional and political context as a result of the changing nature of industrial relations in the global market economy more generally. The former president of Confindustria, Luca Cordero di Montezemolo, suggests that social partners and government need to agree that the role of social concertation is one of the most relevant factors for economic growth. Accordingly, in a recent document, Confindustria also suggests that industrial relations are a crucial 'element of competitiveness' for the national economy and that a 'constitutional pact' between the social partners is necessary. ${ }^{7}$ The new centre-left government takes the same position; however, the social actors continue to disagree over the reforms for a new model of bargaining structure and stronger rules for union representativeness. CGIL maintains its position in favour of a law on union representativeness as the first step; however, CISL and UIL would prefer to prioritise a reform of the collective bargaining system. Likewise, while CGIL argues for the need to negotiate productivity wages at the national level (because small firms are not equipped to undertake decentralised bargaining), CISL and UIL argue that they do not want to lose their emphasis on associative and pragmatic unionism. The results of these conflicts lead to difficulties in reaching a compromise.

The difficult relationship between (and within) the social partners on the one hand and the national urgency to negotiate on different and various aspects (e.g. the public sector, job stability in the labour market and welfare and pension reform) on the other, add to the difficulties facing the current centre-left government in enforcing social concertation. Many questions remain unanswered, especially with regard to the outcomes of those negotiations that have been successfully concluded, such as the agreement concerning job stability for young people with temporary and insecure jobs in the public sector. Furthermore, the electoral programme presented by the centreleft party, the Ulivo, highlights the wish to abolish legislation passed by the Berlusconi government that establishes from 1 January 2008 the application of accelerated savings to those aged 57 to 60 years old (the so-called 'scalone' or 'big step'); however, the difficulty in reaching such an agreement on the seniority pension using small gradual steps is that it slows down the process of social concertation. The same problem has arisen with reform of the 'calculus coefficients' or 'on-the-job financial assistance' (ammortizzatori sociali).

The major current challenge for Italian social concertation is to manage this complexity, to combine such a large number of economic and social interests in the creation of a new social pact for productivity and growth. Many social partners have agreed, during public debates and in documents, that this difficulty does indeed exist, although it can also be argued that the success of the 1993 Ciampi Protocol and the following social pacts up until 1997 is widely acknowledged. Specifically, the implementation of the protocol has seen the maintenance of a low inflation rate. The budget deficit was also reduced: from 9.6 per cent of GDP in 1993 to 2.1 per cent in 2007. The high national debt, being 121.7 per cent of GDP in 1993, was reduced to 105 per cent in 2006. Likewise, unemployment fell from 10.2 per cent in 1993 and 12 per cent in 1996 to less than 7 per cent in 2007, a lower rate than that in France and Germany. Despite these improvements in macroeconomic indicators, the Italian economic

\footnotetext{
${ }^{7}$ See Confindustria, 'Relazioni industriali. Per una maggiore competitività delle imprese, lo sviluppo dell'occupazione e la crescita del paese. Le proposte di Confindustria', Roma, 22 September 2005, and the joint renewal of the National Collective Agreement of Metalworkers, January 2006.
} 
system continues to have difficulties in removing itself from the traditional conditions of family and 'nano' capitalism, which has led to a vicious cycle characterised by a lower quality of work, increased demand for lower-skilled work, increasingly limited interest by Italian families in investing in education (leading to fewer educated workers), and correspondingly, lower productivity levels. Moreover, the growing role of small- and medium-sized enterprises and the restructuring of industrial districts towards longer and global networks remain hindered by the ineffectiveness of public administration.

Low productivity means low wages and the crucial question upon which the future revitalisation of the Italian social concertation will depend will arguably need to deal with this issue: how can we increase productivity in order to redistribute more wages? The 1993 Ciampi Protocol and the concluding remarks by the Giugni Commission on the same protocol in 1997 have indicated the answer to this question: to give greater, although controlled, space to the decentralised levels of collective bargaining. However, as we have seen, a lack of consensus (and practice) on this recommendation prevails among the social actors, due mainly to their long and traditional conflicting strategies in industrial relations. The current Prodi government is on the path of returning to social concertation; accordingly, Prodi has established negotiations with the social actors on welfare and the labour market. Thus, he has openly ignored the indications provided by the Berlusconi government, which were based on a more rapid decision-making process and direct relationships between social actors, in favour of separate agreements; however, as in the past, the success of this new path will arguably depend on the extent to which the social parties have (and will have) concrete reasons to sit at the table of social concertation.

\section{Acknowledgements}

The original version of this article was presented at the European Sociological Association Conference in Torun (September 2005). The authors wish to thank the editor and anonymous referees for stimulating comments on an earlier version of this article. We would like also to thank Tony Royle for his useful remarks in the editing of the article.

\section{References}

Alacevich, F. and L. Burroni (2001), 'Collective Bargaining, Social Pacts and Employment Policies in Italy. Towards a New Model of Industrial Relations', in M. Alaluf and C. Prieto (eds), Collective Bargaining and the Social Construction of Employment (Brussels, ETUI) pp. $77-101$.

Bellardi, L. (1999), Concertazione e contrattazione. Soggetti, poteri e dinamiche regolative (Bari, Cacucci).

Carrieri, D. (2001), Agire per accordi (Rome, Ediesse).

Carrieri, D. (2003), 'Introduzione', Quaderni di Rassegna Sindacale, A Dieci Anni dal Protocollo 1993, 3, 3, 23-31.

Cella, G. and T. Treu (eds) (1998), Le nuove relazioni industriali. L'esperienza italiana nella prospettiva europea (Bologna, Il Mulino).

Dell'Aringa, C. and S. Negrelli (2005), Dopo il '93. Gli studi di relazioni industriali dal Protocollo Ciampi ad oggi (Milan, Angeli).

EIRR (2003), 'Italy: Labour Market Reforms are Finally Approved', European Industrial Relations Review, 350, March, 28-30. 
European Foundation for the Improvement of Living and Working Conditions (1991), European Employment and Industrial Relations Glossary: Italy (London, Sweet \& Maxwell).

Ferrera, M. and E. Gualmini (2004), Rescued by Europe? Social and Labour Market Reforms in Italy from Maastricht to Berlusconi (Amsterdam, Amsterdam University Press).

Giugni, G. (2003), La lunga marcia della concertazione (Bologna, Il Mulino).

Gunnigle, P., G. McMahon and G. Fitzgerarld (1999), Industrial Relations in Ireland: Theory and Practice (Dublin, Gill \& Macmillan).

Hancke, B. and M. Rhodes (2005), 'EMU and Labour Market Institutions in Europe: The Rise and the Fall of National Social Pacts', Work and Occupations, 32, 2, 196-228.

Hassel, A. (2003), 'The Politics of Social Pacts', British Journal of Industrial Relations, 41, 4, 707-726.

Léonard, E. (2001), 'Industrial Relations and the Regulation of Employment in Europe', European Journal of Industrial Relations, 7, 1, 27-47.

Léonard, E. (2005), 'Governance and Concerted Regulation of Employment in Europe', European Journal of Industrial Relations, 11, 3, 307-326.

Mania, R. and G. Sateriale (2002), Relazioni pericolose. Sindacati e politica dopo la concertazione (Bologna, Il Mulino).

Mariucci, L. (2004), 'Concertazione e unità sindacale. Tre tesi e tre domande', Lavoro e Diritto, 2, 2, 267-276.

Negrelli, S. (2000), 'Social Pacts in Italy and Europe: Similar Strategies and Structures; Different Models and National Stories', in G. Fajertag and P. Pochet (eds), Social Pacts in Europe-New Dynamics (Brussels, ETUI) pp. 85-112.

Negrelli, S. (2004), 'The Territorial Pacts in Italy: The Competitive Corporatism Assumption in Question', in R. Salais and R. Villeneuve (eds), Europe and the Politics of Capabilities (Cambridge, Cambridge University Press) pp. 73-90.

Negrelli S. (2006), 'Concertazione. Gli equivoci e le priorità', Il Diario del Lavoro, 4 July. http://www.ildiariodellavoro.it (accessed July 2006).

Negrelli, S. and P. Sheldon (2004), 'Employment Relations in Italy', in G. Bamber, R. Lansbury and N. Wales (eds), International and Comparative Employment Relations. Globalisation and the Developed Market Economies (Crows Nest, Allen \& Unwin) pp. 146-175.

Pulignano, V. (2003), 'Union Struggle and the Crisis of Industrial Relations in Italy', Capital and Class, 79, January.

Regalia, I. and M. Regini (1997), 'Employers, Unions and the State: The Resurgence of Concertation in Italy?', West European Politics, 20, 1, 220-230.

Regalia, I. and M. Regini (1998), 'Italy: The Dual Character of Industrial Relations', in A. Ferner and R. Hyman (eds), Changing Industrial Relations in Europe (Oxford, Blackwell) pp. 459-503.

Regalia, I. and M. Regini (2004), 'Collective Bargaining and Social Pacts in Italy', in H. C. Katz, W. Lee and J. Lee (eds), The New Structure of Labor Relations (Ithaca, NY, Cornell University Press) pp. 59-83.

Regini, M. (1997), 'Still Engaging in Corporatism? Recent Italian Experience in Comparative Perspective', European Industrial Relations Review, 3, 3, 259-278.

Regini, M. (2000), 'Between Deregulation and Social Pacts: The Responses of European Economies to Globalisation', Politics and Society, 28, 1, 5-33.

Rhodes, M. (2001), 'The Political Economy of Social Pacts: "Competitive Corporatism" and European Welfare Reform', in P. Pierson (ed.), The New Politics of the Welfare State (Oxford, Oxford University Press) pp. 165-194.

Roche, W. K. and J. F. Geary (2000), “"Collaborative Production” and the Irish Boom: Work Organization, Partnership and Direct Involvement in Irish Workplaces', Economic and Social Review, 31, 1, 1-36.

Salvati, M. (2000), 'Breve storia della concertazione all'Italiana', Stato e Mercato, 60, 3, $447-476$. 
Schmitter, P. C. and J. R. Grote (1997), 'Sisifo corporatista: passato, presente e futuro', Stato e Mercato, 50, 2, 183-215.

Siegel, N. A. (2005), 'Social Pacts Revisited: "Competitive Concertation” and Complex Causality in Negotiated Welfare State Reforms', European Journal of Industrial Relations, 11, 1, $107-126$.

Traxler, F., S. Blaschke and B. Kittel (2001), National Labour Relations in Internationalised Markets (London, Routledge).

Treu, T. (2001), Le politiche del lavoro in Italia (Bologna, Il Mulino).

Tronti, L. (2003), 'Politica dei redditi e concertazione. Tra bilanci e prospettive', Quaderni di Rassegna Sindacale, 3, 3, 32-44.

Visser, J. (1998), 'Two Cheers for Corporatism, One for the Market: Industrial Relations, Wage Moderation and Job Growth in the Netherlands', British Journal of Industrial Relations, 36, 2, 269-292.

Visser, J. and A. Hemerijck (1997), A Dutch Miracle (Amsterdam, Amsterdam University Press). 